\title{
Veszélyesanyag-tároló tartály üzemeltetésének iparbiztonsági feltételrendszere
}

\section{Industrial Safety Conditions for the Operation of Dangerous Substance Storage Tanks}

Az 5 m³$^{3}$-nél nagyobb ürtartalmú atmoszférikus veszélyesfolyadék-tároló tartályoknak nemcsak a létesitése, hanem az üzembe helyezése, az üzemeltetése és a megszüntetése is szigorú elöirásokhoz kötött. A vonatkozó engedélyezési eljárásban párhuzamosan több hatóság is érintett, ugyanakkor a cél közös, az üzemeltetönek bizonyitania kell a veszélytelen müködést. A veszélytelen müködés dokumentálásának és ellenörzési, vizsgálati módszereinek számos katasztrófavédelemi, iparbiztonsági aspektusa van. A szerző jelen publikációban a veszélytelen állapot igazolásához szükséges müszaki, szervezési feltételrendszert ismerteti, részeletesen bemutatva az eljáró hatóságok szerepkörét.

Kulcsszavak: veszélyes anyag, tárolótartály, tartálysérülés, üzembe helyezés, üzemeltetés, felszámolás, karbantartás

Not only the construction, but also the commissioning, operation and decommissioning of atmospheric hazardous liquid storage tanks with a capacity of more than $5 \mathrm{~m}^{3}$ are subject to strict regulations. Several authorities are involved in the relevant permitting procedures, but the goal is common, the operator has to prove safe operation. There are many aspects of disaster management and industrial safety in the documentation and control of non-hazardous operation and test methods. The author describes the system of technical and organisational conditions necessary to prove the safe condition, presenting in detail the role of the acting authorities.

Keywords: dangerous substance, storage tank, tank damage, commissioning, operation, elimination, maintenance

Nemzeti Közszolgálati Egyetem Víztudományi Kar Víz- és Környezetbiztonsági Tanszék, mérnök, e-mail: berger. adam@uni-nke.hu 


\section{Bevezetés}

A 2009-2019 közötti időszakban mintegy 309 veszélyes anyaggal kapcsolatos baleset következett be. Annak ellenére, hogy a veszélyes technológiák biztonsági színvonala folyamatosan növekszik, a nulla kockázati szint továbbra sem érhető el. ${ }^{2}$ A fenntartható fejlődés, a kapacitásnövelés, a termelésbiztonság egyik kulcskérdése a megfelelő mennyiségű alapanyag rendelkezésre állása. Általánosságban elmondható, hogy napjainkban a szállításban keletkező bizonytalanság miatt egyre több veszélyes anyagokkal foglalkozó üzem, küszöbérték alatti üzem, kiemelten kezelendő létesítmény tervezi új $5 \mathrm{~m}^{3}$-nél nagyobb atmoszférikus veszélyesanyag-tároló tartály (tárolótartály) létesítését. Szakirodalom alapján elmondható, hogy a tartálysérülés kiváltó okai között számos esetben valamilyen mulasztás, meghibásodás szerepel. ${ }^{3}$ A tipikusnak mondható sérülések többsége a karbantartási munkálatok elvégzésével kiküszöbölhető. Ilyen általános sérülés, hiba például a betonburkolat és a tartályfal közötti hézag, vagy a csatlakozócsonkokon kialakuló repedés. ${ }^{4}$

A katasztrófavédelemröl és a hozzá kapcsolódó egyes törvények módositásáról szóló 2011. évi CXXVIII. törvény (Katasztrófavédelmi törvény) 25. § (1) bekezdésében foglaltak szerint „veszélyes anyagokkal foglalkozó üzemre, veszélyes anyagokkal foglalkozó létesítményre építési engedély csak a hivatásos katasztrófavédelmi szerv (a IV. fejezet alkalmazásában: iparbiztonsági hatóság) katasztrófavédelmi engedélye alapján adható. Veszélyes tevékenység kizárólag az iparbiztonsági hatóság katasztrófavédelmi engedélyével végezhető". 5

A tárolótartály tervezésére, létesítésére vonatkozó információkat - felhívva a figyelmet többek között a „létesítés” és az „építés” definíciók közötti anomáliára, az iparbiztonsági hatóság szerepkörére - $A$ veszélyes anyag tárolótartály tervezésének katasztrófavédelem-iparbiztonsági aspektusai címü publikációban összefoglaltam. Jelen publikációban a gondolatmenetet továbbviszem: a tartály használatbavételi engedélyezéséhez, üzemeltetéséhez, karbantartásához, valamint a felszámoláshoz, a tevékenység megszüntetéséhez kapcsolódó legfontosabb ismeretek bemutatásával, kiegészítve azt saját tapasztalatokkal, ajánlásokkal.

A tárolótartályhoz kapcsolódó tevékenység megkezdésénél, illetve az üzemeltetés során a Budapest Föváros Kormányhivatalának egyes ipari és kereskedelmi ügyekben eljáró hatóságként történő kijelöléséröl, valamint a területi mérésügyi és müszaki biztonsági hatóságokról szóló 365/2016. (XI. 29.) Korm. rendeletben foglaltak alapján a fővárosi és megyei kormányhivatal hatóságként jár el. ${ }^{6}$ Ugyanakkor a tárolótartály a Katasztrófavédelmi törvény 3. §-a alapján veszélyes anyagokkal foglalkozó létesítménynek, a kapcsolódó tevékenység veszélyes tevékeny-

2 Cimer Zsolt - Kátai-Urbán Lajos - Vass Gyula: Katasztrófakockázatok: a településrendezési tervezés szerepe a megelőzésben. In Hábermayer Tamás (szerk.): Katasztrófák, kockázatok, önkéntesek. Szekszárd, Tolna Megyei Katasztrófavédelmi lgazgatóság, 2020. 56-63.

3 Petr Trávníček et alii: Prevention of an atmospheric storage tank bund failure. Journal of Loss Prevention in the Process Industries, 70. (2021), 104438. 9.

4 Lyubomir Zdravkov - Mariya Pantusheva: Typical damage in steel storage tanks in operation. Procedia Structural Integrity, 22. (2019), 291-298.

5 2011. évi CXXVIII. törvény a katasztrófavédelemről és a hozzá kapcsolódó egyes törvények módosításáról.

6 365/2016. (XI. 29.) Korm. rendelet Budapest Főváros Kormányhivatalának egyes ipari és kereskedelmi ügyekben eljáró hatóságként történő kijelöléséről, valamint a területi mérésügyi és műszaki biztonsági hatóságokról. 
ségnek minősül. Ezért a folyamatban a fővárosi és megyei kormányhivatal mellett az iparbiztonsági hatóság önálló hatóságként jelenik meg. Ez azt jelenti, hogy egy tárolótartály általános értelemben vett használatbavétele során a vízügyi és tűzvédelem jogkörökben a katasztrófavédelem a veszélyes folyadékok vagy olvadékok tárolótartályainak, tároló-létesítményeinek müszaki-biztonsági hatósági felügyeletéröl szóló 216/2019. (IX. 5.) Korm. rendeletben foglaltak szerint szakhatóságként, iparbiztonsági jogkörben önálló hatóságként jár el. ${ }^{7}$ A publikációban ezért bemutatom a két engedélyeztetési eljárás kapcsolódási pontjait.

\section{Tárolótartály üzembe helyezésének engedélyeztetése}

A tárolótartály, tárolólétesítmény üzembe helyezésének engedélyeztetési eljárása vonatkozásában több aspektus is érvényesül, amelyeket az alábbiakban ismertetek.

\subsection{Katasztrófavédelmi-iparbiztonsági engedélyeztetés}

A tervezési fázis végeredményeként az építési engedélyezési dokumentáció alapján készített kiviteli tervek szerint kezdődik meg a tárolótartály elemeinek gyártása, valamint a helyszíni összeszerelés (létesítés).

Az iparbiztonsági szakértő a kivitelezés során folyamatosan felügyeli, hogy a létesítési engedélyezési dokumentációban foglaltak megvalósulnak-e. Amennyiben el kell térni a létesítési engedélyezési dokumentációban foglaltaktól, értékelni kell a változást, meg kell vizsgálni, hogy a mennyiségi kockázatelemzésre milyen hatással van. Már a létesítési engedélyezési dokumentáció elkészítésekor a tervezők az iparbiztonsági szakértővel együttműködve meghatározták az üzemeltetéshez szükséges felügyeleti (monitoring-) rendszerek körvonalait, ugyanakkor a folyamatszabályozás pontos kialakítása - programozása - a kivitelezés során valósul meg. A folyamatirányítási rendszer kialakításánál javasolt látható és hallható előriasztások, figyelmeztetések definiálása, valamint a felügyeleti eszközök meghibásodásának jelzésére a meghibásodás tényéről is hibajelzés beprogramozása. Például túltöltés elleni védelem céljából javasolt több előriasztás, majd végső tiltás, vagy tárolótartályban lévő folyadékszint csökkenésére - a kihelyezett gázérzékelőkön és szivárgásfigyelőkön túl - figyelmeztetés, jelzés programozása, így azonnal észlelhető, ha kitárolási tevékenység nélkül is szintcsökkenés tapasztalható. A folyamatirányítási szabályozásnál javasolt követni a figyelmeztetés - riasztás - tiltás hármas elvet.

A tárolótartály veszélyes anyaggal történő feltöltése előtt a Katasztrófavédelmi törvény 25. §-a szerinti engedélyezési eljárást kell lefolytatni. Az engedélyezéshez szükséges biztonsági dokumentáció elkészítése az alábbiak szerint történik:

- Amennyiben az üzem nem tartozott a Katasztrófavédelmi törvény IV. fejezetének hatálya alá, de a tárolótartály üzembe helyezésével már igen, úgy a státusznak megfelelő biztonsági dokumentáció elkészítése szükséges. A biztonsági jelentés tartalmi

216/2019. (IX. 5.) Korm. rendelet a veszélyes folyadékok vagy olvadékok tárolótartályainak, tároló-létesítményeinek müszaki-biztonsági hatósági felügyeletéről. 
követelményeit a veszélyes anyagokkal kapcsolatos súlyos balesetek elleni védekezésröl szóló 219/2011. (X. 20.) Korm. rendelet 3. melléklete a belső védelmi tervét a 8. melléklet, a biztonsági elemzését a 4 . melléklet, a súlyos káresemény elhárítási tervét az 5 . melléklet tartalmazza. ${ }^{8}$

- Veszélyesanyag-tároló tartály használatba vétele történhet veszélyes anyagokkal foglalkozó üzemben, küszöbérték alatti üzemben, kiemelten kezelendő létesítményben is. Amennyiben a tárolótartály a Katasztrófavédelmi törvény IV. fejezetének hatálya alá tartozó üzemeltetőnél létesül, meg kell vizsgálni, hogy az üzembe helyezés okoz-e státuszváltozást.

- Amennyiben az új tárolótartály üzembe helyezése státuszváltozást okoz, akkor az új státusznak megfelelő típusú biztonsági dokumentációt - felső küszöbértékű veszélyes anyagokkal foglalkozó üzembiztonsági jelentés és belső védelmi terv, alsó küszöbértékű veszélyes anyagokkal foglalkozó üzembiztonsági jelentés és belső védelmi terv - kell a szakértőnek elkészíteni és az iparbiztonsági hatóság részére benyújtani.

- Amennyiben az új tárolótartály üzembe helyezése státuszváltozást nem okoz, a már meglévő biztonsági dokumentációt - biztonsági jelentés és belső védelmi terv, biztonsági elemzés és belső védelmi terv vagy súlyos káresemény-elhárítási terv-kell felülvizsgálni. A felülvizsgálatnak ki kell terjedni a biztonsági dokumentáció teljes tartalmára, az üzem környezetétől kezdve a technológiai információkon és a veszélyeztetés elemzésén át egészen az irányítási rendszerig benne foglalva a védelmi infrastruktúrát.

A biztonsági dokumentáció elkészítésénél, felülvizsgálatánál javasolt kiindulni egy előzetes következményelemzésből, amelynek eredményeként a veszélyeztetett környezet - ahol a halálozás valószínűsége a legsúlyosabb esetben nagyobb, mint 1\% - lehatárolható. A továbbiakban a következményelemzéssel lehatárolt, veszélyeztetett területen kell a lakott területet, a gazdálkodó szervezeteket felmérni, tekintettel arra, hogy a mennyiségi kockázatelemzés során a társadalmi kockázat meghatározásakor a népesség elhelyezkedése az egyik meghatározó inputadat.

A biztonsági dokumentációban be kell mutatni a tárolótartály elhelyezkedését, müszaki adatait, amelyhez alapot nyújt a létesítési engedélyezési dokumentáció, valamint az időközben elkészült kiviteli terv. A tárolótartály védelmi és jelzőrendszereinek leírásánál javasolt kitérni a másodlagos védelemre - védőgyürü/kármentő kialakítás -, valamint az összes folyamatirányítási monitoring-rendszerelemre, azok szabályozási mechanizmusaira. A használatbavétel előtt ki kell dolgozni a normál és nem normál üzemi állapotokra - így a betárolási, tárolási, kitárolási és a veszélyhelyzeti tevékenységre - vonatkozó technológiai utasításokat. A technológiai utasításokban szerepeltetni kell a folyamatirányítást biztosító monitoring-rendszerelemeket, az azok által generált jeleket - figyelmeztetés, riasztás, tiltás, meghibásodás - és a kapcsolódó operátori intézkedéseket. A technológiai utasításban egyértelműen szabályozni kell a feladatés hatásköröket, valamint a veszélyhelyzeti intézkedéseket, amelyek a belső védelmi terv alapjául is szolgálnak. Bár nem jogszabályi kritérium, de a technológiai utasítás mellett javasolt már 
az egyes beépített rendszerelemekre a gyártói iránymutatás és a jogszabályi előírások alapján kidolgozni az éves karbantartási tervet.

A biztonsági dokumentációban a tervezésnél készített veszélyelemzést pontosítani kell a folyamatirányítási rendszer (monitoringrendszer), valamint a védelmi infrastruktúra (például automata oltórendszer) kockázatcsökkentő hatásaival. A belső dominóhatás eredményeit is figyelembe véve azonosítani kell a lehetséges veszélyes anyagokkal kapcsolatos súlyos baleseti eseménysorokat, és meg kell határozni a gyakoriságukat, továbbá következményelemzéssel a lehetséges hatásukat. Számos esetben a gyakoriság- és következményelemzés során műszakilag alátámasztott szakértői becsléseket kell alkalmazni, tekintettel arra, hogy egyes kockázatcsökkentő intézkedések nem, vagy csak nagyon nehezen számszerűsíthetők. A veszélyelemzés végeredményét - halálos hatások, halálozás egyéni kockázata, társadalmi kockázat, környezetterhelés - össze kell vetni a 219/2011. (X. 20.) Korm. rendelet 7. mellékletében szereplő kritériumokkal. Amennyiben a tervezésnél az iparbiztonsági szakértő kellő alapossággal járt el, és a létesítés során a kiviteli tervtől jelentős eltérés nem történt, várhatóan a hatásterületek kisebbek lesznek - hiszen a kockázatcsökkentő folyamatirányítási és monitoringrendszerek figyelembevétele most történik -, a tárolótartály és a kapcsolódó tevékenységek engedélyezhetők.

Használatbavétel előtt - a tárolótartály veszélyes anyaggal történő megtöltését megelőzően - ki kell dolgozni az esetleges veszélyhelyzetek kezelésére (kárelhárítás), valamint a környezet mentesítésére (eredeti állapot visszaállítása) vonatkozó intézkedési sorokat, amelyeket a belső védelmi tervbe kell beépíteni.

A tárolótartály üzembe helyezését megelőzően biztonságtechnikai ellenőrzéseket kell elvégezni, és az eredményeket jegyzőkönyvben rögzíteni. A biztonságtechnikai ellenőrzések körét a 2.3. alfejezet foglalja össze. A jegyzökönyveket az engedélyeztetés során lefolytatandó helyszíni szemle alkalmával be kell tudni mutatni a hatóság részére.

A hatóság a kérelem elbírálása során vizsgálja egyrészt, hogy az üzem tevékenysége - beleértve az új tartály üzemeltetését - jelent-e a környezetére, a lakosságra nagyobb veszélyeztetést a 219/2011. (X. 20.) Korm. rendelet szerinti kritériumoknál, másrészt az üzemeltető felkészült-e egy esetleges veszélyes anyagokkal kapcsolatos üzemzavar, súlyos baleset elhárítására.

\subsection{Műszaki biztonsági és egyéb engedélyeztetési eljárások}

A veszélyes folyadékok vagy olvadékok tárolótartályainak, tárolólétesítményeinek müszaki-biztonsági hatósági felügyeletéről szóló 216/2019. (IX. 5.) Korm. rendelet a létesítésre vonatkozó általános szabályok és követelmények mellett kitér az üzembe helyezésre, üzembe vételre, javításra, átalakításra, időszakos ellenőrzésre és a megszüntetésre is. A rendelet értelmében nemcsak a tárolótartály létesítése, hanem annak üzembe helyezése is hatóságiengedély-köteles. Az üzembe helyezés engedélyeztetési dokumentációjában az alábbi elemeknek kell szerepelniük:

1. Kivitelezői nyilatkozat.

2. Az előírt vizsgálatok, ellenőrzések bizonylatai és igazolása:

- a kivitelezés megfelelt-e a létesítési/átalakítási tervben foglaltaknak; 
- alkalmas-e a biztonságos használatra;

- rendelkezésre állnak-e a tárolótartályok, technológiai szerelvények, tartozékok, csővezetékek és berendezések megfelelőségigazolásai;

- rendelkezésre állnak-e a technológiai szerelvények, tartozékok bizonylatai.

3. A kisebb hiányosságok, hibák pótlásának vagy javításának teljesítési határideje. ${ }^{9}$

Abban az esetben, ha nem új tárolótartály, tárolólétesítmény üzembe helyezéséröl, hanem már az üzemeltetés során keletkező vagy felmerülő hibák javításáról van szó, akkor az üzemeltetőnek a javítást előzetesen be kell jelentenie az engedélyezési hatóság részére. A bejelentésnek tartalmaznia kell a javítási tervdokumentációt, a tervezői nyilatkozatot, és hogy a javítás pontosan mely területre terjed ki (elrendezésre vonatkozó helyszínrajz). Továbbá be kell mutatni a tárolótartály, tárolólétesítmény jelenlegi állapotát és általános műszaki állapotát (műszaki leírás, tervrajz). Végezetül a tervezett átalakítás vagy javítás pontos ismertetése szükséges a tervezett munkálatok részletezésével. Az üzembevételi eljárás során a kérelemnek tartalmaznia kell az üzembehelyezési dokumentáció mellett a tartályvizsgálati jelentést, valamint a kivitelezési dokumentációt, amelynek az alábbi fő részei vannak:

1. kivitelezői nyilatkozat a müszaki dokumentációban foglaltaknak való megfelelőségről;

2. bizonylat a tervező által előírt vizsgálat(ok)ról;

3. jegyzőkönyv a szilárdsági és tömörségi nyomáspróbáról;

4. jegyzőkönyvek, bizonylatok az eredeti állapot helyreállításáról. ${ }^{10}$

A hatóság a kérelem elbírálása során:

- vizsgálja, hogy a tárolótartály, tárolólétesítmény a létesítési engedélyben vagy az átalakítási bejelentésben foglaltaknak megfelelően valósult-e meg;

- vizsgálja, hogy a tárolótartály, tárolólétesítmény biztonságos használatra alkalmas állapotban van-e;

- vizsgálja a megfelelöségigazolás meglétét és beazonosíthatóságát mind a tárolótartályok, mind a technológiai szerelvények és tartozékok, csővezetékek és berendezések tekintetében;

- vizsgálja a technológiai szerelvények, tartozékok bizonylatait.

Hasonlóan az iparbiztonsági engedélyeztetéshez, a tárolótartály üzembe helyezését megelőző biztonságtechnikai ellenőrzésekről szóló jegyzőkönyveknek rendelkezésre kell állniuk az engedélyeztetési eljárás lefolytatásához.

A müszaki-biztonsági hatósági felügyeleten kívül az egyes szakági hatóságoknál - például tűzvédelmi kérdéskörben az illetékes területi katasztrófavédelmi kirendeltségnél, környezetvédelmi engedélyeztetés a területileg illetékes környezetvédelmi és természetvédelmi főosztálynál - szintén meg kell kezdeni a hatáskörükbe tartozó berendezések üzembe helyezésének engedélyeztetését. Az engedélyeztetési eljárások egymással párhuzamosan lefolytathatók.

\footnotetext{
216/2019. (IX. 5.) Korm. rendelet.

10 216/2019. (IX. 5.) Korm. rendelet 10. § (1) bekezdés.
} 


\section{3. Üzembe helyezést megelőző biztonságtechnikai ellenőrzések}

Az üzembe helyezést megelőzően minimum az alábbi vizsgálatok, ellenőrzések elvégzése szükséges:

A tartályok alapozásának, süllyedésének és dőlésének vizsgálata: a tartályalap állapotát szemrevételezéssel, a dőlést és süllyedést geodéziai méréssel kell ellenőrizni.

Tartály szerkezeti vizsgálatai. A berendezésen általában vizuális ellenőrzéssel végzett vagy kezdődő vizsgálatsorozat, amelynek célja a veszélyes meghibásodások feltárása, ellenőrzése, megelőzése, a szerkezet biztonságtechnikai szempontból való megfelelőségének megállapítása.

Napjainkban a veszélyes anyagokat tároló tartályokat jellemzően dupla fenékkel látják el. Ebből adódóan a fenéklemezek varratainak ellenőrzésére is ki kell térni. A dupla fenéklemez esetén a vizsgálatokat mind a két lemeznél el kell végezni, hiszen a fenékrész tömörsége csak igy biztosítható. A fenéklemezek és a fallemezek összekötését szolgáló sarokvarratokat a fenékvarratokhoz hasonlóan kell vizsgálni. A tartály építésének befejezését követően a fenéklemezek közötti zárt tér ellenőrzése vákuumtartás-vizsgálattal történik.

Az álló hengeres tartályok esetében az építés övenként történik, amely során megfelelő nagyságú táblákat hegesztenek össze. Az alsó öveket jellemzően vastagabb, a felső öveket pedig vékonyabb lemezek felhasználásával alakítják ki. A hossz- és körvarratok ellenőrzése részleges vizsgálattal történik. A tartályok esetében a varrattalálkozások vizsgálata kiemelt jelentőségü, hiszen erőátadás szempontjából a legkritikusabb pontok/helyek közé tartoznak.

Az ellenőrzés első lépése a vizuális és a felületi repedésvizsgálat (mágneses vagy penetrációs), ezt követően a további ellenőrzési vizsgálatok radiográfiai vagy ultrahangos módszerrel végezhetők. A radiográfiai módszer csak akkor alkalmazható, ha a tartály falvastagsága kisebb, mint $8 \mathrm{~mm}$. Az ultrahangos vizsgálatot ennél nagyobb falvastagság esetén is lehet alkalmazni. A radiográfiás vizsgálat nagy előnye a jó dokumentálhatóság. Az ultrahangos módszer viszont kedvezőbb költséggel és gyorsabb kivitelezhetőséggel rendelkezik.

Az ellenőrzések alkalmával fontos pont azon csövek hegesztési varratainak vizsgálata is, amelyek a tartályokba csatlakoznak. A csatlakozócsonkoknál - és az átmenő csöveknél - a galléros kialakítás terjedt el. Jellemzően túlnyomásos eljárással történik a gallér és az általa takart terület tömörségvizsgálata. Az eljáráshoz egy, a galléron erre alkalmas menetes furat készítése szükséges. Ehhez a furathoz történik a kompresszor, illetve a nyomásmérő csatlakoztatása. ${ }^{11}$

Tömörségi próba. A tömörségi próba a hitelesítés legnagyobb töltetén, 24 órán keresztül történő nyomástartásból áll. A próba során figyelni kell a folyadékszintet és a palást szivárgásmentességét. Mérősúlyos mérőszalaggal történik a folyadékszint mérése. A 4 órás periódusokban elvégzett mérés bázispontja a tartálytetőn kiválasztott bázissík. A próba során mért értékek rögzítése jegyzőkönyvben történik. ${ }^{12}$

A tartály tömörségi próbájával együtt a hitelesítését is el kell végezni.

R.U.M. Testing: Tartályok és nyomástartó edények vizsgálata.

Petrol Plus Kft.: Tartályvizsgálat. 
A müszerek vizsgálata. Az üzembe helyezést megelőzően ellenőrizni kell a szintmérőket, szintkapcsolókat és szintmutatókat, a túltöltésgátló berendezést, túltöltésjelzőt, az előjelzőt, a szintmérőket, a mintavevőt, a hőmérsékletmérőt és a nyomásmérőt.

A szintmérők, szintkapcsolók és szintmutatók vizsgálatánál a szintmérőműszer-érzékelő szabad mozgásának, a műszerkábel mozgáslehetőségének, a műszerúszó tömítettségének, a szintmérőzsinór épségének és a müködéspróbának az ellenőrzésére kell kitérni.

A túltöltésgátló berendezés esetében a rezgővilla (vagy úszó) folyadékba történő merítésével elő kell idézni a túltöltés jelenségét, és figyelni kell, hogy a betárolóvezetékbe épített motoros szerelvény az elzárást megvalósította-e vagy sem. Ellenőrizni kell továbbá az operátorhelyiségben a túltöltésjelek meglétét, valamint helyességét.

A túltöltésjelzőt v. előjelzőt a tartály palástjából ki kell szerelni, és a rezgővilla (vagy úszó) folyadékba történő merítésével elő kell idézni a túltöltés jelenségét. Ellenőrizni kell a visszajelző helyiségbe érkező túltöltésjelek meglétét, valamint helyességét.

A tartályon lévő szintmérő berendezés működőképességét, valamint a mért értékek helyességét ellenőrizni kell szemrevételezéssel, valamint a szintmérő berendezés operátorhelyiségbe történő visszajelzését és a kijelzett értékek helyességét, beleértve a tartálynál a „nulla" értékét. A mintavevő vizsgálata során a védőcsövet, a mintavevőhuzalt, a hőmérők mozgatásának lehetőségét és a mintavevőfedél működőképességét és a tömítés állapotát kell ellenőrizni.

A működési próba során ellenőrizni kell, hogy a hibákról visszajelzés - általában hangés fényjelzés - érkezik-e az operátorhelyiségbe. Az eredményt jegyzőkönyvben kell rögzíteni. Az ellenőrzéskor javasolt a tartály üzemeltetésére vonatkozó technológiai utasítást is kontrollálni, felülvizsgálni.

Villámvédelmi felülvizsgálat. A villámvédelmi vizsgálatot az Országos Tüzvédelmi Szabályzatról szóló 54/2014. (XII. 5.) BM rendelet (OTSZ) írja elő, az érvényes szabvány alapján kell elvégezni. A villámvédelmi vizsgálat célja a villámhárító berendezés alkalmasságának megállapítása a villámok felfogására és levezetésére, a villámlás káros hatásaival szemben a létesítmény és az ember megvédésére. A létesítés közben már ellenőrizni kell azokat az alkatrészeket, amelyeket eltakarnak, majd a villámhárító átadása előtt el kell végezni az első felülvizsgálatot. ${ }^{13}$

Villamos és érintésvédelmi szabványossági felülvizsgálat. Új villamos berendezés beüzemelése előtt a vonatkozó szabvány szerinti első felülvizsgálattal, valamint az OTSZ szerinti tűzvédelmi szabványossági felülvizsgálattal kell igazolni, hogy a villamos kivitelezés a terveknek megfelelően és szabványosan lett elvégezve. Az első felülvizsgálat alkalmából csak hibátlan jegyzőkönyv adható ki. Ha a felülvizsgáló valamilyen szabványossági hibát talál, a hibát ki kell javítani, és csak utána lehet a jegyzőkönyvet kiállítani az első felülvizsgálatról.

Érintésvédelmi szabványossági felülvizsgálatot a munkaeszközök és használatuk biztonsági és egészségügyi követelményeinek minimális szintjéröl szóló 10/2016.(IV. 5.) NGM rendelet szerint minden esetben el kell végezni új berendezés vagy villamos kivitelezés létesítésekor a munka befejezése után, a használatbavétel előtt. Az érintésvédelmi vizsgálat célja, hogy kiszűrje és megelőzze a villamos berendezések érintéséből származó áramütéses baleseteket. A baleset jellemzően úgy következik be, hogy a villamos berendezés külső burkolatának érinté-

13 54/2014. (XII. 5.) BM rendelet az Országos Tüzvédelmi Szabályzatról. 
sekor a munkavállalót áramütés éri. A burkolatnak üzemszerűen feszültségmentesnek kellene lennie, meghibásodás, zárlat következtében azonban feszültség alá kerülhet. Az érintésvédelmi szabványossági felülvizsgálat vizuális ellenőrzésből és műszeres mérésből áll. ${ }^{14}$

Tüzjelző és beépített automata oltóberendezés. A tüzjelző és a beépített automata oltóberendezés üzembe helyezését az illetékes területi katasztrófavédelmi kirendeltség engedélyezi. Az engedélyezéshez benyújtandó engedélyezési dokumentáción túl - amelynek tartalmi elemeit az OTSZ, valamint a „Beépített tűzoltó berendezések tervezése, telepítése” című tűzvédelmi műszaki irányelv tartalmazza - az engedélyezés teljes körű meggyőződéssel teljesül, ha az alábbiak ellenőrzése megtörtént: oltóberendezés működőképessége, jelzések tesztelése, tűzjelzővezérlések, amennyiben az oltóberendezést működtetik, megvalósulási tervtől való eltérés, üzemeltetési napló, indokolt esetben tartalék szórófejek megléte, kapcsolási rajz, zónakiosztási rajz, feliratok megléte, tűzgátló átvezetések.

Munka- és tűzvédelmi üzemeltetői bejárás. Az üzembe helyezés előtt a munkavédelmi és tűzvédelmi szakirányú jogosultsággal rendelkező szakértőkkel helyszíni bejárást kell tartani, amelyeknek ki kell terjedni a biztonságos használati szabályok ellenőrzésére, többek között a lépcsőkre, létrákra, korlátokra, pódiumokra, a feliratok és a tűzvédelmi infrastruktúra meglétére.

\section{A tárolótartály üzemeltetése}

A tárolótartály, tárolólétesítmény üzemeltetése során több aspektus is érvényesül, amelyeket az alábbiakban ismertetek.

\subsection{Katasztrófavédelmi-iparbiztonsági aspektusok}

A tárolótartály üzemeltetése során a biztonsági dokumentációban foglaltakat kell betartani. A tárolótartályban töltetcsere, más veszélyes anyag tárolása csak akkor hajtható végre, ha a változásnak nincs veszélyes anyagokkal kapcsolatos súlyos baleset kockázatát növelő vagy védelmi rendszert érintő hatása. Ellenkező esetben a töltetcsere az új feltételeket bemutató katasztrófavédelmi-iparbiztonsági engedélyezést követően lehetséges.

A katasztrófavédelmi hatóság a tárolótartályok üzemeltetését rendszeresen ellenőrzi, amely kiterjed a tárolótartályban tárolt veszélyes anyag típusára és mennyiségére, a tárolótartály műszaki állapotára szemrevételezéssel, valamint a karbantartási jegyzőkönyvek vizsgálatával, a technológiai utasítás(ok) meglétére és az érintett munkavállalók oktatására.

Az ellenőrzések tárgyköre összhangban van az iparban bekövetkező balesetek tapasztalati eredményeivel, miszerint a balesetek döntő részét emberi mulasztás, műszaki meghibásodás vagy több tényező együttes ráhatása okozza (1. ábra).

14 10/2016. (IV. 5.) NGM rendelet a munkaeszközök és használatuk biztonsági és egészségügyi követelményeinek minimális szintjéről. 


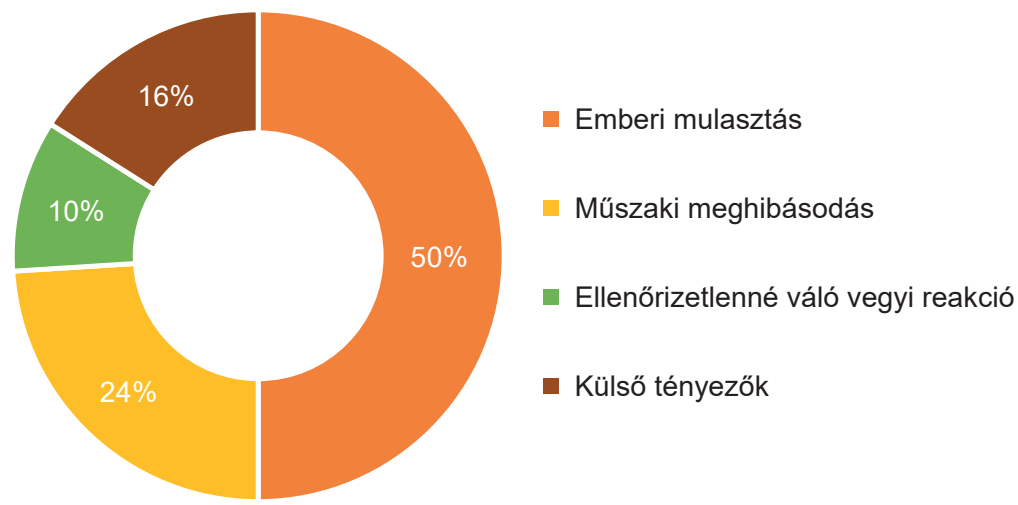

1. ábra. A súlyos ipari balesetek elsődleges okai

Forrás: a szerző szerkesztése Kátai-Urbán Lajos et alii: Módszertani segédlet a veszélyes anyagokkal kapcsolatos súlyos ipari balesetek elleni védekezés területi és helyi feladatainak ellátásához. Budapest, BM Országos Katasztrófavédelmi Főigazgatóság - Akaprint Kft., 2005.

Ahogyan az 1. ábrán is látható, a karbantartással, illetve annak hiányosságaival összefüggő események kiváltotta műszaki meghibásodás magas részarányt képvisel az ipari baleseteket kiváltó okok között. Egy adott üzem szempontjából azonban az öregedés egy komplex aspektusú jelenség. Ennek oka, hogy az nem merül ki az eszközök, berendezések, különböző szerkezetek fizikai öregedési jelenségeiben, hanem az eljárások, technológiák, a szervezeti rendszer és a személyi állomány elavulását, öregedését is magában hordozza. A fentiekben leírtakkal támaszható alá, hogy az időszakos hatósági ellenőrzések során az adott üzemet érintő öregedési aspektusok átfogó ellenőrzése, vizsgálata szükséges. ${ }^{15}$ A műszaki állapot nyomon követésére szolgáló, illetve karbantartási rendszerek vizsgálata során alkalmazandó főbb kérdések a következők:

- Meghatározták-e a biztonság szempontjából kritikus berendezéseket a veszélyes anyagokkal kapcsolatos súlyos baleseti eseménysorok vonatkozásában?

- A biztonság szempontjából kritikus berendezések, műszerek és alkatrészek nyilvántartása könnyen hozzáférhető módon és naprakészen van-e tartva?

- Az üzemeltető determinisztikus módszerek vagy állapot-nyomonkövetés alapján

- határozza meg a berendezések, műszerek, eszközök élettartamát?

- A berendezések, alkatrészek, műszerek cseréjére vonatkozóan alakítottak-e ki ütemtervet?

- Leosztották-e (munkakörökhöz és/vagy üzemeltetési egységekhez) az egyes karbantartási felelősségeket és feladatokat? (Például külső karbantartási munka megrendelése; belső karbantartási feladat elrendelése; elvégzett karbantartási munka ellenőrzése, jóváhagyása; a karbantartó személyzet képzése, oktatása, felkészítése [külső és belső esetén is].)

- Kiépítettek-e monitoringrendszert a meghibásodások előjeleinek jelzésére, a meghibásodások jelentésére?

15 Cimer Zsolt - Tóth László: Irányítási rendszer és a vállalati menedzsment szerepe a súlyos ipari balesetek megelőzésében. In Hábermayer Tamás (szerk.): Katasztrófák, kockázatok, önkéntesek. Szekszárd, Tolna Megyei Katasztrófavédelmi lgazgatóság, 2020. 49-55. 
- A jogszabályokban, szabványokban előírtak és az üzemeltetési tapasztalatok alapján alakítottak-e ki tesztelési, felülvizsgálati és karbantartási rendszert?

- Az üzemeltető az egyes tesztelések, felülvizsgálatok és karbantartások során számol-e a lehetséges várható károsodásokkal (például kopás, vibráció, atmoszferikus kibocsátás)?

- Meghatároztak-e megelőző karbantartási munkálatokat, azok eljárásai ki vannak-e alakítva, illetve azok épülnek-e a súlyos baleseti veszély- és kockázatelemzésre?

- Az eljárások figyelembe veszik-e az egyes berendezések, müszerek, tárolótartályok, alkatrészek, eszközök műszaki sajátosságait, valamint a sajátos üzemeltetési körülményeket?

- Kialakítottak-e monitoringrendszert arra vonatkozólag, hogy az egyes tesztelési, felülvizsgálati, karbantartási programok végrehajtása dokumentálható, ellenőrizhető, visszakereshetö legyen?

- Kellő figyelmet kapnak-e az üzemeltető részéről a nehezen hozzáférhető, sajátos technológiai körülmények között üzemelő berendezések, a kritikus pontok, müszaki állapotok? ${ }^{16}$

A fentiekben leírt ellenörző kérdések is rávilágítanak arra, hogy a karbantartásnak kiemelt jelentősége van a súlyos ipari balesetek megelőzésében. A tárolt veszélyes anyag, a tárolótartály, tárolólétesítmény, a kapcsolódó müszaki berendezések, infrastruktúrák és környezeti tényezők alapján különböző karbantartási stratégiák alkalmazhatók, melyek összefoglalását az 1. táblázat tartalmazza.

1. táblázat. Karbantartási stratégiák

\begin{tabular}{|c|c|c|c|c|}
\hline & Hibajavító & Előirányzott & Állapotfüggő & Megelőzés \\
\hline $\begin{array}{l}\text { Alkalmazási } \\
\text { terület }\end{array}$ & $\begin{array}{l}\text { kisebb kár, kiesés esetén; } \\
\text { nagy szórású hibamen- } \\
\text { tes működés esetén }\end{array}$ & $\begin{array}{l}\text { nagy kockázattal járó } \\
\text { kiesés esetén; } \\
\text { állandó élettartamú } \\
\text { rendszerelemek esetén; } \\
\text { előkészíthető munkála- } \\
\text { tok esetén }\end{array}$ & $\begin{array}{c}\text { mérhető, elemezhető } \\
\text { munkálatok esetén; } \\
\text { nagy kockázatú } \\
\text { meghibásodások esetén; } \\
\text { gazdaságossági szem- } \\
\text { pontok érvényesülése } \\
\text { esetén }\end{array}$ & $\begin{array}{c}\text { kiemelt kockázatú } \\
\text { meghibásodás esetén; } \\
\text { müszakilag megoldható } \\
\text { munkálatok esetén }\end{array}$ \\
\hline Információigény & gyors és azonnali & $\begin{array}{c}\text { előzetesen és pontosan } \\
\text { begyűjtött }\end{array}$ & $\begin{array}{c}\text { állandó vagy ciklikus } \\
\text { adatszolgáltatás az ál- } \\
\text { lapotról }\end{array}$ & $\begin{array}{l}\text { üzemeltetés közben } \\
\text { nincs }\end{array}$ \\
\hline Szervezés & $\begin{array}{l}\text { gyors beavatkozás; } \\
\text { csomagterv szerinti }\end{array}$ & $\begin{array}{l}\text { tervezett; } \\
\text { ütemezett }\end{array}$ & $\begin{array}{c}\text { van idő a felkészülésre, } \\
\text { az állapotvizsgálat } \\
\text { kiemelt jelentőségű }\end{array}$ & $\begin{array}{l}\text { üzemeltetés közben } \\
\text { nincs }\end{array}$ \\
\hline Szervezet & $\begin{array}{l}\text { helyi, univerzális, szak- } \\
\text { képzett, kreatív }\end{array}$ & $\begin{array}{c}\text { központosított; } \\
\text { külső erők bevonása }\end{array}$ & $\begin{array}{c}\text { központosított; } \\
\text { külső erők bevonása }\end{array}$ & $\begin{array}{c}\text { üzemeltetés közben } \\
\text { nincs }\end{array}$ \\
\hline Vezetés szerepe & gyors döntés & tervezés & stratégiai vezetés & $\begin{array}{c}\text { üzemeltetés közben } \\
\text { nincs }\end{array}$ \\
\hline
\end{tabular}

Forrás: a szerző szerkesztése Mesics Zoltán - Laczkó Levente - Domján Iván: Útmutató a müszaki állapot nyomon követéssel és a karbantartással kapcsolatos biztonsági irányitási rendszerelemek hatékony kialakitásához és müködtetéséhez. Budapest, BM Országos Katasztrófavédelmi Főigazgatóság, 2020 alapján

16 Belügyminisztérium Országos Katasztrófavédelmi Főigazgatóság: Ellenőrzési terva BM OKF területi szervei részére a 2021. évi veszélyes üzemekkel kapcsolatos iparbiztonsági hatósági ellenőrzésifeladatok végrehajtására. Mellékletek, 4/A számú melléklet. 
A tárolótartály, tárolólétesítmény és a kapcsolódó berendezések, eszközök állapotának ellenőrzése során szemrevételezéssel jól észrevehetők az állapotromlás vizuális jelei (például korrózió, törés, repedés, süllyedés). Ugyancsak szemrevételezéssel ellenőrizendő a tárolótartályra és a tárolóanyagra vonatkozó megfelelő felirat, jelölés megléte. A biztonságos működés, valamint a műszaki állapot nyomon követése és a karbantartás jelző-/elörejelző rendszerének üzemképessége érdekében kiemelt figyelmet kell fordítani a segédenergia-vezetékek, az üzemközi vezetékek, illetve a kiszolgáló infrastruktúra ellenőrzésére, működőképességének fenntartására.

A tárolótartály, tárolólétesítmény üzemeltetése során rendkívüli eseménynek minősül a környezetkárosodás vagy környezetveszélyeztetés, illetve az idegen ingatlanon, létesítményben vagy egyéb vagyontárgyban bekövetkezett károkozás. Ekkor az üzemeltetőnek kötelessége minden olyan tevékenységet, intézkedést megtenni, amely a veszélyeztetés szintjének és a kár mértékének minimalizálására irányul. Ez jelentheti a helyszín megváltoztatását is annak érdekében, hogy az emberi élet, testi épség, jelentős érték megóvása biztosított legyen, azonban ezt minden esetben dokumentálni kell. A rendkívüli esemény bejelentését követően a hatóság kivizsgálást indít, amelynek során megállapítja a rendkívüli esemény okát és körülményeit. Fontos kiemelni, hogy a hatóság a vizsgálat befejezése előtt is hozhat tiltó, korlátozó intézkedéseket, valamint a tárolótartály, tárolólétesítmény további használatát és az ismételt üzembe helyezés feltételeit is engedélyhez kötheti. ${ }^{17}$ A dominóhatások, külső kockázatok, veszélyforrások vizsgálata során ellenőrizendő főbb tényezők a hősugárzás, a túlnyomás, a repeszhatás, valamint az esetleges más fizikai, kémiai hatás és annak mértéke, amelyek dominóhatáshoz vezethetnek.

\subsection{Müszaki biztonsági aspektus}

Annak érdekében, hogy az üzemeltetés során a tárolótartály, tárolólétesítmény továbbra is megfeleljen a jogszabályi és a Müszaki biztonsági szabályzatban előírt biztonsági követelményeknek, időszakos hatósági ellenőrzéseket kell tartani. A meghatározott periódusonként végrehajtott belső tisztítás, szerkezeti vizsgálat és tömörségi próba jelenti a tárolótartály, tárolólétesítmény időszakos ellenőrző vizsgálatát, amelyet az üzemeltetőnek kell elvégeztetnie. Az időszakos ellenőrző vizsgálat módját a Műszaki biztonsági szabályzat határozza meg. Az általánosságban előírt ciklusidő belső tisztítás és szerkezeti vizsgálatok esetében 10 év, tömörségi próba vonatkozásában pedig 5 év. Az üzemeltető kérelmére a hatóság a soron következő szerkezeti vizsgálat és/vagy belső tisztítás elvégzésének határidejét - jogszabályban meghatározott feltételek együttes teljesülése esetén - meghosszabbíthatja, amely fekvő hengeres szimplafalú, és állóhengeres szimplafenekü tartályok esetében 1 évet jelent, és maximum két alkalmat. ${ }^{17}$

17 216/2019. (IX. 5.) Korm. rendelet. 


\section{A tárolótartály üzemeltetésének szüneteltetése, megszüntetés}

A Katasztrófavédelmi törvény 27 . § (2) bekezdése szerint az üzemeltető az iparbiztonsági hatóság számára köteles haladéktalanul bejelenteni a veszélyes anyagokkal foglalkozó létesítmény, például tárolótartály - ideiglenes leállítását, végleges bezárását. ${ }^{18}$

\subsection{Katasztrófavédelmi-iparbiztonsági aspektusok}

A veszélyes tevékenység ismételt folytatásakor az üzemeltető köteles a 219/2011. (X. 20.) Korm. rendelet szerint meghatározott felülvizsgálati eljárást kezdeményezni az iparbiztonsági hatóságnál. A veszélyes tevékenység csak akkor tekinthető befejezettnek, ha a tárolótartályból a veszélyes anyagot elszállították, és a tartály tisztítása is megtörtént. A tisztítatlan tárolótárolótartály ugyanolyan veszélyesnek tekinthető a benne lévő gőzök miatt, mint a töltött tartály. A veszélyesanyag-elszállítást és a tárolótartály-tisztítást dokumentáltan kell tudni igazolni.

\subsection{Müszaki biztonsági aspektus}

A tárolótartály, tárolólétesítmények esetében megkülönböztetünk szüneteltetési és megszüntetési állapotot. Az első esetben időszakos üzemen kívüli állapot áll fenn, azaz a tárolótartály, tárolólétesítmény egésze vagy csak egy része 12 hónapot meghaladóan van üzemen kívüli állapotban. A második eset pedig a végleges felszámolását jelenti.

A tárolótartály, tárolólétesítmény szüneteltetését az azt megelőző 15 napon belül be kell jelenteni a hatóság részére, valamint a bejelentéshez mellékelni kell a tárolótartály-tisztítási jegyzőkönyvet. A szüneteltetés ideje alatt az üzemeltető ugyan mentesül az időszakos ellenőrző vizsgálatok alól, azonban a hatóságnak benyújtott ismételt üzembe vételi bejelentésnél csatolni kell a megfelelő eredményű és 3 hónapnál nem régebbi időszakos ellenőrző vizsgálati jegyzőkönyvet. A szimpla falú, fekvőhengeres tartályok esetében a bejelentés további melléklete a tartályvizsgálói szakvélemény és a tömörségi próba jegyzőkönyve. A szüneteltetés csak és kizárólag úgy történhet, ha a tárolótartály, tárolólétesítmény, azok része vagy berendezése a használatból ki van vonva, ha a tartály üres, kitisztított, valamint a működő technológiai rendszerröl mechanikusan leválasztott állapotban van. ${ }^{19}$

Az üzemeltetés szüneteltetéséhez hasonlóan a megszüntetés is a hatóságnak tett előzetes bejelentés alapján történik, és a bejelentéstől számított 2 éven belül meg kell szüntetni. A bejelentés részét képező műszaki dokumentáció főbb tartalmi elemei a következők:

- tervezői nyilatkozat;

- az adott időpontban érvényes állapotot bemutató elrendezési rajz;

- térképmásolat, amelyen a megszüntetendő tartály, tárolólétesítmény fel van tüntetve;

- a megszüntetendő tartályról, tárolólétesítményről, valamint a megszüntetés módjáról való egyszerűsített műszaki leírás;

2011. évi CXXVIII. törvény.

19 216/2019. (IX. 5.) Korm. rendelet. 
- tartálytisztítási jegyzőkönyv(ek);

- a megszüntetési jogosultságot igazoló dokumentum;

- tartályvizsgálói szakvélemény. ${ }^{20}$

\section{5. Összefoglalás}

A veszélyesanyag-tároló tartály üzembe helyezése, azaz a veszélyes tevékenység megkezdése szigorú jogszabályi feltételhez kötött. A Budapest Főváros Kormányhivatalának egyes ipari és kereskedelmi ügyekben eljáró hatóságként történő kijelöléséről, valamint a területi mérésügyi és műszaki biztonsági hatóságokról szóló 365/2016. (XI. 29.) Korm. rendeletben foglaltak alapján a veszélyes folyadékok és olvadékok - nyomástartó berendezésnek nem minősülő - tárolótartályai és tárolólétesítményei üzembe helyezésének engedélyezését hatóságként a fővárosi és megyei kormányhivatal végzi. A műszaki-biztonsági hatósági felügyeleten kívül az egyes szakági hatóságoknál - például tűzvédelmi kérdéskörben az illetékes területi katasztrófavédelmi kirendeltségnél, környezetvédelmi engedélyeztetés a területileg illetékes környezetvédelmi és természetvédelmi főosztálynál - szintén meg kell kezdeni a hatáskörükbe tartozó berendezések üzembe helyezésének engedélyeztetését. ${ }^{21}$

A fővárosi és megyei kormányhivatal mellett a Katasztrófavédelmi törvény hatálya alá tartozó üzemeknél az engedélyezési eljárásban a katasztrófavédelem-iparbiztonság önálló hatóságként jelenik meg, a veszélyes tevékenység az engedélye nélkül nem kezdhető meg.

Az engedélyeztetési eljárások egymással párhuzamosan folytathatók, közös kapcsolódási pont, hogy az üzemeltetőnek igazolnia kell a tárolótartály és a kapcsolódó berendezések veszélytelen működését.

A tárolótartály üzemeltetését az engedélyezési dokumentációban és a hatályos engedélyben foglaltak szerint kell végezni. Az üzemeltetés során kardinális kérdés a karbantartás, amelynek végrehajtása egyrészt üzemeltetői feladat, másrészt szaktevékenység, dokumentált megtörténtét a hatóságok folyamatosan ellenörzik.

A tárolótartály megszüntetése ugyancsak engedélyköteles; hasonlóan az üzembe helyezéshez az üzemeltetőnek szintén dokumentáltan igazolnia kell a veszélytelen állapot helyreállítását, azaz a veszélyes anyag elszállítását, valamint a tárolótartály tisztítását.

A tárolótartály létesítésére, üzembe vételére, üzemeltetésére és megszüntetésére vonatkozó szigorú előírásoknak, valamint a hatóságok folyamatos ellenőrzésének köszönhetően hazánkban tárolótartály sérülése miatt a lakosságot is érintő veszélyes anyagokkal kapcsolatos súlyos baleset nem történt.

20 216/2019. (IX. 5.) Korm. rendelet 12. § (1) bekezdés.

21 365/2016. (XI. 29.) Korm. rendelet. 


\section{Felhasznált irodalom}

Belügyminisztérium Országos Katasztrófavédelmi Főigazgatóság: Ellenörzési terv a BM OKF területi szervei részére a 2021. évi veszélyes üzemekkel kapcsolatos iparbiztonsági hatósági ellenörzési feladatok végrehajtására. Mellékletek, 4/A számú melléklet. Online: www.katasztrofavedelem.hu/ application/uploads/documents/2021-01/73325.pdf

Cimer Zsolt - Kátai-Urbán Lajos - Vass Gyula: Katasztrófakockázatok: a településrendezési tervezés szerepe a megelőzésben. In Hábermayer Tamás (szerk.): Katasztrófák, kockázatok, önkéntesek. Szekszárd, Tolna Megyei Katasztrófavédelmi lgazgatóság, 2020. 56-63.

Cimer Zsolt - Tóth László: Irányítási rendszer és a vállalati menedzsment szerepe a súlyos ipari balesetek megelőzésében. In Hábermayer Tamás (szerk.): Katasztrófák, kockázatok, önkéntesek. Szekszárd, Magyarország: Tolna Megyei Katasztrófavédelmi Igazgatóság, 2020. 49-55.

Kátai-Urbán Lajos - Bíróné Ősz Julianna - Bojti Imre et alii: Módszertani segédlet a veszélyes anyagokkal kapcsolatos súlyos ipari balesetek elleni védekezés területi és helyi feladatainak ellátásához. Budapest, BM Országos Katasztrófavédelmi Főigazgatóság - Akaprint Kft., 2005. Online: www.vedelem. hu/letoltes/anyagok/608-modszertani-segedlet-a-veszelyes-anyagokkal-kapcsolatos-sulyos-ipari-balesetek-elleni-vedekezes-teruleti-es-helyi-feladatainak-ellatasahoz.pdf

Mesics Zoltán - Laczkó Levente - Domján Iván: Útmutató a müszaki állapot nyomon követéssel és a karbantartással kapcsolatos biztonsági irányitási rendszerelemek hatékony kialakitásához és müködtetéséhez. Budapest, BM Országos Katasztrófavédelmi Főigazgatóság, 2020. Online: www. katasztrofavedelem.hu/application/uploads/documents/2020-01/68231.PDF

Trávníček, Petr - Petr Junga - Jan Kudělka - Luboš Kotek: Prevention of an atmospheric storage tank bund failure. Journal of Loss Prevention in the Process Industries, 70. (2021), 104438. Online: https:// doi.org/10.1016/j.jp.2021.104438

Zdravkov, Lyubomir - Mariya Pantusheva: Typical damage in steel storage tanks in operation. Procedia Structural Integrity, 22. (2019). 291-298. Online: https://doi.org/10.1016/j.prostr.2020.01.037

\section{Jogi források}

2011. évi CXXVIII. törvény a katasztrófavédelemröl és a hozzá kapcsolódó egyes törvények módosításáról 219/2011. (X. 20.) Korm. rendelet a veszélyes anyagokkal kapcsolatos súlyos balesetek elleni védekezésről

54/2014. (XII. 5.) BM rendelet az Országos Tűzvédelmi Szabályzatról

10/2016. (IV. 5.) NGM rendelet a munkaeszközök és használatuk biztonsági és egészségügyi követelményeinek minimális szintjéről

365/2016. (XI. 29.) Korm. rendelet Budapest Főváros Kormányhivatalának egyes ipari és kereskedelmi ügyekben eljáró hatóságként történő kijelöléséről, valamint a területi mérésügyi és műszaki biztonsági hatóságokról

216/2019. (IX. 5.) Korm. rendelet a veszélyes folyadékok vagy olvadékok tárolótartályainak, tárolólétesítményeinek müszaki-biztonsági hatósági felügyeletéről

\section{Internetes források}

Petrol Plus Kft.: Tartályvizsgálat. Online: http://petrolplus.hu/szolgaltatasok/tartalyvizsgalat/

R.U.M. Testing: Tartályok és nyomástartó edények vizsgálata. Online: https://rumtesting.hu/o_tartaly. html 